\title{
THE NONPROFIT AEROSPACE CORPORATION AS THIRD PARTY SYSTEMS ARCHITECT-ENGINEER
}

\author{
ROBERT T. JENSEN*
}

\section{INTRODUCTION}

The complexity of modern weapon and space systems has required the development of imaginative new management-procurement techniques in government contracting, particularly to apply advanced technology effectively, economically, and objectively.

One technique, pioneered by the Air Force, is the "associate contractor" approach. Under this arrangement the weapon or space system is analyzed and divided into major subsystems which can be contracted for separately. Contracts are then entered into with "associate" contractors for the several portions of the weapon or space system. Concurrently, a contract is entered into with an independent third-party technological contractor to provide the associate contractors, and the government, the necessary scientific and engineering guidance and coordination.

This work on many Air Force weapons and space systems is being performed by The Aerospace Corporation, a nonprofit California corporation organized in 1960 by a group of public-spirited individuals to provide competent and objective scientific and technological services to the government. Aerospace participates in the formulation of requirements and in planning, systems engineering, testing and evaluation. In performing "systems engineering," Aerospace works with the associate contractors and advises the Air Force as to progress, problems, and reorientation necessary to achieve a compatible whole.

The third-party technological contractor is "in the middle" between many rights and responsibilities. Its duties, and its contractual position, are analogous in many respects to those of an architect-engineer performing services in connection with construction. In addition, however, it must necessarily establish and maintain even closer working relationships with, and secure current and sometimes private information from, both the government and the associate contractors.

Success of the technological contractor in this arrangement depends primarily upon its achievement and maintenance of technical competence. Success is also dependent upon its acceptance by industry. Such acceptance depends in part upon careful analyses of the legal aspects of these relationships and development of solu-

* B.S. I949, LL.B. 1949, Northwestern University; LL.M. 1955, University of Southern California. General Counsel, The Aerospace Corporation, Los Angeles, California. Member of the California bar. The Aerospace Corporation is a California nonprofit corporation, organized in the public interest in 1960 to provide objective leadership in the advancement of space science and technology for the U.S. Government. Former member of the legal staff of Douglas Aircraft Company, serving in the office of Gencral Counsel and as counsel for the Douglas EI Segundo Division. 
tions for the inherent problems, such as privity of contract questions, responsibilities of the contractor, access to and protection of private data, and conflicts of interest.

\section{A Brief History}

With the advent of the more complex ballistic missile, concern arose that contractors in the aerospace industry did not have and might not be able to assemble a sufficient across-the-board technical competence to perform expeditiously and effectively the scientific and technological work required. This work was referred to as "systems engineering."

The Air Force, in some of its programs, divided the weapon or space system into major subsystems, each amenable to being contracted for separately. It awarded a contract for each. The several contractors were called "associate" contractors. The Air Force also entered into a separate contract with a third-party technological contractor to provide systems engineering in the integration of the subsystems, accomplishment of the necessary design compromises among them, and definition of interfaces. ${ }^{2}$

Although successful, the introduction of the third-party systems engineer caused concern that it might gain a competitive advantage over the associate contractors from its intimate knowledge and relationship with them and with the government. Ultimately, the Air Force added to its inventory of management techniques that of contracting with the nonprofit Aerospace Corporation as third-party technological contractor, in order to assure maximum corporate objectivity and freedom of information exchange. ${ }^{3}$

\section{II}

Why a Nonprofit Corporatton?

Nonprofit corporations are not new. The laws of many states provide for their creation. The federal and most state laws recognize their dedicated purposes and, accordingly, prescribe income tax exemption for them. ${ }^{5}$

Nor are nonprofit corporations new in the field of furnishing scientific advice and assistance to the federal government. It has been noted that President Andrew Jackson made use of a nonprofit corporation for scientific support in the early I800s, and that a nonprofit organization was used in weapon system development-to develop a self-propelled, man-carrying "aerodrome"-as early as $18988^{\circ}$

\footnotetext{
${ }^{1}$ House Committee on Government Operations, Eleventh Report, H.R. REP. No. II2I, 86th Cong., Ist Sess. (r959).

${ }^{3}$ House Committee on Government Operations, Third Report, H.R. REP. No. 324, 87th Cong., Ist Sess. 3 ff. (196r).

${ }^{3} I d$. at 4,9 , esp. $15 f$.

- Howard L. Oleck, Non-Profit Corporations and Associations, Organization, Management and Dissolution 6, $8 \mathrm{ff}$. (I956).

${ }^{2} I d$. at 336 ff., INT. Rev. CoDE of $x 954, \$ 501$.

'The Non-Profit Corporation, Gimmick or Godsend in Weapon System Development, remarks by
} 
The use of a nonprofit corporation such as the Aerospace Corporation as a thirdparty systems architect-engineer has certain advantages in the public interest. The corporation's purposes must be in the public interest or it will not come into being as a nonprofit corporation and its practices must remain so or it will not endure. Moneys it receives are correspondingly dedicated to the public interest and not siphoned off into other channels. No portion of its earnings may be distributed as dividends or for the benefit of any individual; it may not unreasonably accumulate assets and it may not pay unreasonable salaries. ${ }^{7}$ It cannot engage in commercial activities without risking loss of its tax exemption. 8 Consequently, it poses no threat to industry.

\section{III}

\section{The Function of Aerospace as Third-Party Systems Architect-Engineer}

If each associate contractor were working independently it could proceed unencumbered by need for knowledge of, or communication with, the others. Knowledge gained as the contractors proceed, however, calls for modifications of the original specifications; each modification usually affects the other subsystems. Overall integration of the system, design compromises among subsystems, definition of interfaces, analysis of subsystems, and supervision of system testing must be accomplished. Competent, objective technological analysis and rapid exchange of information are vital. These are the primary purposes of the Air Force's contracts with Aerospace Corporation. Because of the progress industry has made in increased technical competence during the last ten years, it is generally unnecessary for Aerospace to become enmeshed in the detailed work of the associate contractors." Consequently, the Air Force usually contracts with Aerospace for "General Systems Engineering and Technical Direction." Briefly it may be described as follows:

General Systems Engineering. That portion of system engineering dealing with the overall integration of a system, design compromise among subsystems, definition of interfaces, analysis of subsystems, and supervision of system testing; all to the extent required to assure that system concept and objectives are being met in an economical and timely manner.

Technical Direction. That process by which a contractor's work is reviewed; information on progress and problems is exchanged; plans for future work are discussed; and, where it will better achieve Air Force objectives, the contractor's technical effort is modified, realigned, or redirected. ... 10

To fulfill this function, the entity performing it needs the following:

(I) the highest degree of technical competence;

Max Golden, then General Counsel, Dep't of the Air Force, before the Government Contracts and Procurement Law Committee of the Federal Bar Association Annual Convention, Scpt. I4, 196r.

${ }^{7}$ INT. REV. CODE OF I954, $\$ 50 \mathrm{r}-504$.

${ }^{8}$ Id. $\$ \$ 502,504,511-514$.

${ }^{\circ}$ House Committee on Government Operations, Third Report, stipra note 2, at 13 ff., csp. $22,23$.

${ }^{10}$ Headquarters Space Systems Division (SSD) (Air Force Systems Command), SSD Regulation 80-9, Sept. 23, I963. 
(2) access to all the pertinent facts;

(3) ability to effectuate, or have effectuated, its judgments;

(4) the highest degree of integrity;

(5) confidence of the associate contractors and of the government.

\section{IV}

\section{Legal Foundattons for Success}

In view of these needs, Aerospace has found it necessary to seek solutions for a number of legal problems:

I. How does it accomplish the general systems engineering function, which affects the contractual position of others, without privity of contract with them?

2. What are its responsibilities?

3. How does it secure access to information which others might consider "private" information without incurring prohibitive potential liability, and how are others' rights in data protected?

4. How are the government and associate contractors protected against conflicts of Aerospace employees' private interests?

\section{A. Privity of Contract}

The problem which will probably first occur to the lawyer is that there is no privity of contract between Aerospace and the associate contractors. ${ }^{11}$ The associate contractor ordinarily can only be responsive to the party with whom it has a contract-the government. Unless this contractual gap is filled, systems engineering and technical direction cannot be effectively performed.

This void in privity of contract between the associate contractors and Aerospace has been bridged by use of what are referred to as "enabling clauses." 12 The purpose of the enabling clauses is to require the associate contractors to recognize Aerospace's function and to cooperate in its fulfillment. They serve, also, to give the associate contractor contractual protection. One of them provides as follows:

... In the performance of this contract, the Contractor agrees to cooperate with the Aerospace Corporation by responding to invitations to meetings, requests for technical information, and requests for research and development planning data on all matters pertaining to this contract and by discussing with the Aeropsace Corporation employees technical matters relating to this program. The Contractor further agrees to accept technical direction as described herein. ${ }^{13}$

\footnotetext{
${ }^{21}$ For a government contract analogy to the contractual relationship between the government and prime contractor's subcontractor, see Merritt v. United States, 267 U.S. 338 (I925); Sullivan v. United States, I29 Ct. Cl. 65 (1954); Livingston v. United States, ror Ct. Cl. 625 (1944); Borg Warner Corp. v. United States, 340 U.S. 946 (I95I).

19 "Enabling Clause. A group of words placed in an associate contractor's contract by mutual agreement between the Air Force and the associate contractor which permits Aerospace Corporation to perform its appointed duties for the Air Force. ..." SSD Regulation 80-9, stupra note 10.

${ }^{18}$ Ibid.
} 
More legal and contractual hurdles are encountered when inputs from Aerospace affect the associate contractor's contractual obligations-such as requiring a change in specifications, affecting its cost of performance.

Much, if not most, of the advice, recommendations and technical direction by Aerospace does not have a visible effect on the associate contractors' contractual specifications or costs. On occasion the effect is significant. The associate contractor is vitally interested both in the successful performance of its work and in making a reasonable profit. The success of its performance, in the contractual sense, depends upon compliance with the agreed upon specifications, terms, and conditions. It cannot deviate from the specifications nor incur extra costs without the concurrence of its customer. To do so would be to risk disallowance of the cost incurred and, consequently, reduction of profit.

Also, it is the government's position, based on statute and implemented in regulations and contracts, that only a duly authorized representative or agent of the government may obligate the government. ${ }^{14}$ It is said that he alone may authorize a contract "change" or authorize a contractor to incur additional costs to be reimbursed by the government. Individual contracting officers, too, are reluctant to place authority in the hands of others on the basis it might later be found to have been an improper delegation of duties and responsibilities.

To resolve these issues, another portion of one of the "technical direction" definitions provides as follows: "Technical Directives. Where contractual change is involved or where the Air Force, the Aerospace Corporation, or the contractor may so request, specific technical direction will be formalized as serially-numbered Air Force/Aerospace 'Technical Directives' (TDs)."15

\section{B. Responsibilities}

The function of the third-party systems architect-engineer, as noted above, is most closely analogous to the work customarily performed by an architect-engineer in connection with construction work. In the absence of any statutory or case law on the point, this analogy would seem appropriate in analyzing another legal aspect of the systems architect-engineer's position: responsibility.

The duties and liabilities of an architect may be described as follows:

The duty owed by an architect to his employer is that he will exercise and apply his skill and ability, judgment and taste, reasonably and without neglect. . . . Both the owner and the contractor are entitled to rely upon the architect's judgment, and he must exercise all his professional skill and knowledge as an expert in advising them....

\footnotetext{
${ }^{14}$ Pierce v. United States, Dover Five Cent Bank v. United States (The Floyd Acceptance Cascs), 74 U.S. (7 Wall.) 666 (I868); Jay Cooke v. United States, 9r U.S. 389 (1875); Salomon v. United States, 7 Ct. Cl. 482 (I87I); Armed Services Procurement Regulation x-201.3 and I-402, 32 C.F.R. $\$ \$$ I.20I-3 and 1.402 (Supp. 1963); and see for example, Air Force Procurement Instruction $\$ 1$, Pt. 4, 32 C.F.R. $\S$ r.001 (Supp. 1963).

${ }^{18}$ SSD Regulation 80-9, supra note 10.
} 
The architect will be held responsible for all the duties he is required to perform under the contract, and an architect's duty to direct and inspect construction work carries with it the duty to condemn work which he considers unfit. ... 16

An architect is bound to perform to professional standards. He is bound to exercise reasonable care, apply an intelligence befitting his profession, and perform proper investigation and have sufficient knowledge of the subject matter, in all its details. He must use reasonable and ordinary care and diligence in the application of his knowledge to accomplish the purpose for which he is employed. The possession of these characteristics and abilities is implied in his contract. ${ }^{17}$ They are similarly implied in Aerospace's contract with the government for general systems engineering and technical direction.

Were Aerospace given authority to make final decisions or act as an arbitrator, its position could be likened to that of an agent of the owner, and its duties and liabilities would increase. It would bear the liability of an agent and would probably bear liability in the order of magnitude applicable under common law rules of negligence liability. ${ }^{18}$ The government, however, does not delegate to Aerospace the powers of an agent or final arbiter, and in the final analysis its powers are those of a corporate professional technical advisor to the government.

The high standards of performance legally imposed upon Aerospace as a systems architect-engineer under the principles noted-when added to the inherent motivation to perform well which stems from its origins and its professional stature-assure the public of a professional attitude that is deeply responsible.

\section{Private Information: Access and Protection}

A thoughtful look at the close relationships which contribute to successful performance by the third-party systems architect-engineer brings the realization that it must have access to a wide range of the associate contractors' data and other information. It is not enough to base a scientific or technological judgment on incomplete facts. And when "all" of the facts are required, some private associate contractor data must be included.

Outside the protection afforded by the patent system lies a vast store of information and data which can be protected only if kept secret. It may consist of a formula, pattern, device, or compilation of information which is used in one's business, and which gives him an opportunity to obtain an advantage over competitors who do not know or use it. In the absence of breach of contract, abuse of confidence, or impropriety in the means of procurement, such secrets may be copied as freely as devices or processes which are not secret. ${ }^{19}$ Protection is afforded only by a general duty

${ }^{20} 6$ C.J.S. Architects $\$$ I7 (1937).

${ }^{17} 6$ C.J.S. Architects $\$$ I7 (I937); 3 AMr. JuR. Architects $\S 19$ (I936); 5 AM. Jur. 2d Architects $\S 23$ (1962); Witherspoon, When Is An Architect Liable?, 48 A.B.A.J. 321 (1962).

18 Witherspoon, stupra note 17.

${ }^{10}$ Restatement, Torts $\$ 757$ and comment (1939); Note, Protection and Use of Trade Secrets, 64 Harv. L. Rev. 976-86 (I95I); see also, Annot., I70 A.L.R. 449 (1947). 
of good faith. Liability rests upon breach of this duty; that is, breach of contract, abuse of confidence, or impropriety in the method of ascertaining the secret.

Government contractors in the aerospace industry historically have attempted to protect unpatented information by "trade secret" techniques. They limit its distribution and endeavor to establish confidential relationships and impose restrictive legends when necessity requires that it be communicated to others. They withhold it from their competitors; they may withhold it from the government for fear it might be used as the basis for soliciting bids from their competitors. Validity of these fears might be debated but their existence is unquestioned. ${ }^{20}$ The liability of the government for misuse of such private information and the ability of the contractor to secure a satisfactory recovery also have been questioned. ${ }^{21}$

Then, how is Aerospace to have access to this information when it is part of the pertinent data? To receive it entails running the risk of suit for breach of the confidential relationship and facing loss of reputation for integrity. Potential conflicts of interests are encountered since it might be necessary to communicate the information to the government. On the other hand, a policy of refusing the data creates ignorance in an area where knowledge is of major importance to the nation's interests.

One solution to this dilemma has been well received. It is to accept all essential information, giving special handling to that which the other party considers to be proprietary information or a trade secret. The associate contractors are assured that the information will be given the care and protection a prudent technological contractor would give its own proprietary information, with the caveat that it must be given to the government if required. This assurance is coupled with appropriate internal control practices and procedures. If the associate contractor is not satisfied by a review of the recipient's attitudes and reputation and its policies and procedures applicable to others' proprietary data, the problem can be resolved by negotiation of a special contract outlining the parties' rights and duties with respect to specifically identified data.

\section{Protection Against Employees' Conflicts of Interests}

What is conflict of interest? During the past year the President, the Attorney General, and the Congress of the United States have participated in renewed attempts to define and regulate conflicts of interests of employees and consultants to the government. ${ }^{22}$ This is but the latest in a long history of such endeavors.

\footnotetext{
${ }^{20}$ Beach, A Question of Property Rights: The Government and Industrial Know How, 4 I A.B.A.J. 1024-27, 1085-87 (1955).

${ }_{21}$ Harris, Trade Secrets as They Affect the Government, 18 Bus. LAw. 613-26, esp. 614, 615, 617 (I963); Klein, The Technical Trade Secret Quadrangle: A Sttrvey, 55 Nw. U. L. Rev. 437 (1960).

${ }_{22}$ Pub. L. No. 87-849, 76 Stat. III9 (I962), I8 U.S.C.A. $\$ 201$ et seq. (Supp. 1963). Department of Justice Memorandum Regarding Conflict of Interest Provisions of Public Law No. 87-849, Jan. 28, 1963, 28 Fed. Reg. 985 ( (963) $_{3}$; The President's Memorandum on Preventing Conflicts of Interests on the Part of Special Government Employees, May 2, 1963, 28 Fed. Reg. 4539 (1963).
} 
It is generally accepted, however, that the clarity and utility of the conflict of interest laws applicable to government employees have been less than satisfactory. ${ }^{23}$

Nevertheless, not even such legislative sanctions as these are available to the private employer. It has available the civil law remedies arising out of the masterservant relationship. But these are more remedial than preventive.

If it is to perform well its third-party systems architect-engineer function, Aerospace Corporation must maintain an especially high degree of integrity and respect. It is constantly subject to suspicion that its associations with, and the interests of its employees and officers or trustees in, other companies might lead to more favorable treatment or prejudice in favor of one company over another. It must be in a position to assure the associate contractors and the government that it has taken satisfactory measures to minimize the possibility of its employees acting for it in matters involving or affecting their private economic interests. It needs not only to find and remove the few who might consciously do so, but also to give direction to the well-intentioned who might otherwise do so.

Policies imposing high standards of conduct must be adopted and promulgated widely if these goals are to be achieved. A procedure requiring periodic disclosures to top management of the outside interests of all employees in sensitive positions can provide a way of discovering potential conflicts and eliminating them in advance. Enforcement of these requirements-both during the employment relationship and after it is terminated - can be facilitated by making them a part of the individual's express or implied contract of employment. And, of course, the effectiveness of these procedures over the long run will depend upon the strictness and fairness with which they are enforced.

These, in essence, are the policies Aerospace has adopted. They appear to have served the need and been well received by both industry and the government. ${ }^{24}$

Prognosis

Finality in the development of management-procurement techniques is not to be expected in such a dynamic field. Studies of when to contract with nonprofit corporations and when to contract with industry have been and continue to be made. ${ }^{25}$ The relationships of the Air Force and nonprofit corporations have been given considerable scrutiny. ${ }^{26}$ Conflict of interest aspects of defense contracting

${ }^{23}$ See Ass'n of the Bar of the City of New York, Special Committee on Federal Conflict of INTERest Laws, Conflict of INTERest and Federad Service (I960).

${ }^{34}$ See House Comm. on Government Operations, Thirteenth Report, H.R. REP. No. 9I7, 88th Cong., rst Sess. 86,87 ( 1963$)$.

${ }^{25}$ U.S. Bureau of the Budget, Report to the President on Government Contracting for Research and Development (the Bell Report), S. Doc. No. 94, 87th Cong., 2d Sess. (I962); Department of Defense Directive No. 5500.10, Rules for Avoidance of Organizational Conflicts of Interest, June I, I963; Armed Services Procurement Regulation (ASPR) I-II3.2, 32 C.F.R. § I.II3-2 (Rev. 3, Nov. 15, I963).

${ }^{20}$ Policies on Relations with Air Force Sponsored Nonprofit Corporations, issued by Eugene Zuckert, Secretary of the Air Force, Sept. 22, 196r. 
and employment as a whole, as well as in the use of nonprofit corporations, are currently under consideration. ${ }^{27}$

The use of the associate contractor management-procurement technique is one of many tools available to the government today. The use of a nonprofit corporation as a third-party systems architect-engineer in this arrangement is a refinement which appears to resolve many of the problems which have been recognized in the course of its evolution. Its implementation has necessitated resolution of other, incidental problems.

As modern technology continues to advance, more problems will arise and their solutions must be derived. But the use of a nonprofit corporation as thirdparty systems architect-engineer in the associate contractor management-procurement technique is today a successful, working arrangement.

${ }^{27}$ House Comm. on Government Operations, Thirteenth Report, H.R. REP. No. 917, 88th Cong., Ist Sess. ( 1963$)$. 